\title{
Application of meta-analysis in plant pathology: a case study examining the impact of fungicides on wheat yield loss from the yellow spot-septoria nodorum blotch disease complex in Western Australia
}

\author{
Kawsar P. Salam • Geoff J. Thomas • Ciara Beard • \\ Robert Loughman • William J. MacLeod • \\ Moin U. Salam
}

Received: 19 August 2011 / Accepted: 17 March 2013 /Published online: 23 April 2013

(C) The Author(s) 2013. This article is published with open access at Springerlink.com

\begin{abstract}
This work was done to demonstrate the opportunities provided by application of meta-analysis in plant pathology. It was a case study used to determine the effectiveness of foliar fungicides in minimising yield loss from a complex of yellow spot (Pyrenophora tritici-repentis) and septoria nodorum blotch (Stagonospora nodorum, teleomorph: Phaeosphaeria nodorum) (YS-SNB disease complex) on wheat in the northern grain-belt of Western Australia. Fortyseven datasets of experimental results from 14 growing seasons, using 18 varieties sprayed one to three times, predominantly with tebuconazole or propiconazole fungicides, were analysed. Across the datasets, the wheat yield gain from fungicide application was $297 \mathrm{~kg} \mathrm{ha}^{-1}$ with a $95 \%$ confidence interval of $11.6 \mathrm{~kg} \mathrm{ha}^{-1}$. Significant yield gains resulted from single or multiple applications of fungicides. Both propiconazole and tebuconazole, increased yield of wheat affected by the YS-SNB disease complex, with yield gain
\end{abstract}

K. P. Salam $(\bowtie) \cdot$ G. J. Thomas $\cdot$ R. Loughman • W. J. MacLeod · M. U. Salam

Department of Agriculture and Food Western Australia, Locked Bag 4, Bentley Delivery Centre,

Perth, Western Australia 6983, Australia

e-mail: kawsar.salam@agric.wa.gov.au

C. Beard

Department of Agriculture and Food Western Australia, PO Box 110, Geraldton, WA 6530, Australia

W. J. MacLeod

School of Plant Biology, The University of Western Australia,

35 Stirling Highway,

Crawley, WA 6009, Australia from propiconazole being greater than that from tebuconazole. Yield response varied significantly among crop growing seasons. Meta-analysis was able to aggregate a large number of experimental results and answer important questions related to the variables that influenced those results; in this case the effectiveness of fungicides in minimising yield loss from the YS-SNB disease complex on wheat. It also identified areas where further research needs to be done. It is concluded that meta-analysis has the potential to contribute to similar analyses in other crop disease systems.

Keywords Fungicide $\cdot$ Meta-analysis $\cdot$ Pyrenophora triticirepentis · Tan spot · Western Australia · Wheat · Yellow spot · Yield gain · Yield loss · Yield response - Stagonospora nodorum $\cdot$ Septoria nodorum blotch

\section{Introduction}

Wheat (Triticum spp.) is a cereal grain that has significant world-wide importance. Western Australia (WA) plays a vital role in producing wheat, contributing $42 \%$ of the annual national production of about 14 million tonnes in 2007-08 (Anonymous 2010a). It is the dominant species in arable crop cultivation, comprising $64 \%$ of total cropping area (Anonymous 2010b). Wheat from Western Australia is sold predominantly for export markets. Foliar diseases are a significant impediment to wheat production and yield stability in the state. Annual yield losses of about $19 \%$ can be attributed to 16 wheat pathogens, with almost a third of this loss resulting from the yellow spot 
(Pyrenophora tritici-repentis) - septoria nodorum blotch (Stagonospora nodorum, teleomorph: Phaeosphaeria nodorum) (YS-SNB) disease complex (Murray and Brennan 2009).

Yellow spot (synonym: tan spot) (YS) and septoria nodorum blotch (SNB) are the most common foliar diseases affecting wheat production in WA (Bhathal et al. 2003; Shipton 1971; Wiese 1987). They often co-exist in a complex association that is hard to differentiate in the natural environment (Bhathal et al. 2003). While both diseases occur commonly, YS is often predominant on wheat in the northern grain-belt of the Western Australian south-western agricultural region. Fungicide management of foliar diseases of wheat, including YS and SNB, is estimated to cost US\$18.6 million per annum in WA (Murray and Brennan 2009).

Over the last 30 years, many field experiments have been done in WA in order to understand the response of diseases to fungicides and the resultant impact on yield. These experiments were conducted in different seasons and locations with varying disease incidence, in different crop rotations and with a range of wheat varieties with varying resistance to the pathogens that cause these two diseases. While experiments provided vital information related to the diseases and their consequences in the specific experimental conditions, analysis and interpretation of individual experiments does not provide information relating to the general yield response to fungicides in WA. Meta-analysis, developed in the mid-1970s, provides a better opportunity to address that issue (Glass 1976). Meta-analysis is a quantitative approach that estimates a relative response from combined individual studies to determine general trends and differences and identify factors that influence responses. This technique is often used to identify the contexts in which a treatment or intervention is most successful or has the largest effect (Cooper 1989). By synthesising results from many experiments, meta-analysis can give a general quantitative conclusion that a single experiment cannot provide (Adams et al. 1997; Thompson and Pocock 1991). While the technique has been widely used in medicine, pharmacology, human disease epidemiology, education, psychology, business and ecology, its use in plant pathology is new (Rosenberg et al. 2004).

In this paper, we apply meta-analysis to plant disease management using the effect of fungicides on yield loss from the YS-SNB disease complex on wheat in the northern grainbelt of the Western Australian south-western agricultural region as a case study. The study had three objectives: (i) to quantify overall yield response to fungicide application for disease control, (ii) to quantify the yield response as influenced by selected variables, viz. number of fungicide applications, growing season and fungicide active ingredient, and (iii) to assess the economic benefit, if any, from the yield responses.

\section{Materials and methods}

Data source and description

The databases of the Research Information System (RIS) and Research Quality Management Systems (RQMS) of the Department of Agriculture and Food Western Australia (DAFWA) were used for sourcing data. The RIS and RQMS databases archive details of all field experiments done by DAFWA since 1980. The databases were searched using four key words, "fungicide", "yellow spot", "septoria nodorum blotch" and "wheat", and 179 documents were retrieved. Forty-seven out of 179 experiments retrieved from the database were identified as relevant to this study. Experiments where other diseases such as leaf rust or powdery mildew were present together with YS-SNB disease complex were excluded from this analysis. The experiments were all done between 1982 and 2010 in the northern grainbelt of the Western Australian south-western agricultural region (Fig. 1). These experiments investigated the effect of fungicide application on wheat yield and included 18 varieties, one to three applications of fungicide, usually tebuconazole or propiconazole, a wide range of crop growth stages at application, 14 growing seasons and 14 locations. These 14 locations were: Buntine (30.28 S and 116.66 E), Cadoux (30.84 S and 116.73 E), Calingiri (30.89 S and $116.72 \mathrm{E})$, Chapman Valley (28.50 S and 114.79 E), East Ogilvie (28.50 S and 114.79 E), Eradu (28.50 S and 114.79 E), Geraldton (28.80 S and 114.20 E), Mingenew (29.19 S and 115.44 E), Nabawa (28.50 S and 114.79 E), Nanson (28.50 S and 114.79 E), Northampton (28.50 S and 114.79

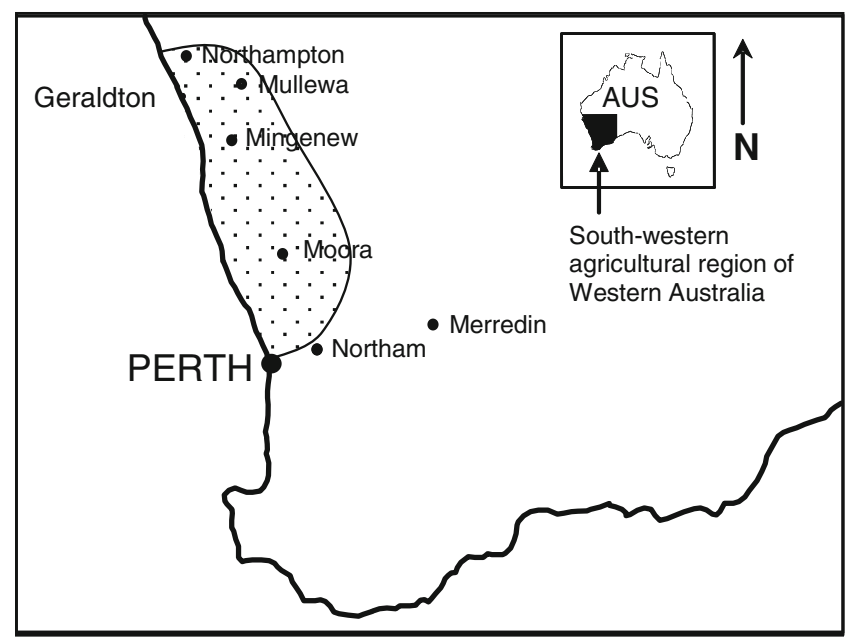

Fig. 1 Northern grain-belt (dotted area) of the south-western agricultural region (shaded area) of Western Australia from where experimental data were used to perform meta-analysis to examine effect of fungicides on wheat yield loss from the yellow spot (Pyrenophora tritici-repentis) — septoria nodorum blotch (Stagonospora nodorum) disease complex 
E), Three Springs (29.69 S, and 115.89 E), Watheroo (30.67 S and 116.14 E), and Yuna (28.50 S and 114.79 E).

The south-western agricultural region of Western Australia has a Mediterranean climate with winter rainfall and moderate winter temperatures (Anderson and Garlinge 2000). The weather in the northern agroecological zone of the south-western agricultural region favours development of yellow spot disease in wheat. Extended rainfall in late winter and early spring with temperatures between 15 and $28{ }^{\circ} \mathrm{C}$ are favourable to the YS-SNB disease complex.

\section{Data analysis}

Details of each experiment (location, seasonal rainfall, wheat variety, experimental treatments, fungicide product and number of applications) and their results were entered into a spreadsheet in MS-Excel ${ }^{\circledR}$ with unique identification. Mean grain yield $\left(\mathrm{kg} \mathrm{ha}^{-1}\right)$ from fungicide-treated and untreated control plots were used to estimate yield responses for each experiment. The yield response is considered as a standard difference between the fungicide treatment and control groups (Shachar and Neumann 2003).

In this study, the mean yield response $(E S)$ was computed by weighting (or standardising) each untransformed yield response by the inverse of its variance (WT) (Lipsey and Wilson 2001):

where,

$\overline{E S}=\frac{\sum(W T \times E S)}{\sum W T}$

$W T=\frac{1}{V}$

When the value of $V$ was not reported in the experimental results, it was estimated (Ngugi et al. 2011) from each experiment:

$V=\frac{n \times\left(\frac{L S D}{1.96}\right)^{2}}{2}$

where $n$ is the number of replicates of each treatment. When $L S D$ was not reported in an experiment, it was estimated:

$L S D=\mathrm{t}_{\text {value }} \times S E D$

where $t$ is the tabulated value and SED is the standard error of difference.

Altogether, there were 225 individual yield responses. In this study, yield responses included zero or negative responses, which were incorporated to avoid bias that has been regarded as a weakness of meta-analysis (Thompson and Pocock 1991).

This analysis included (i) the aggregated (overall) yield response from fungicide application (225 data points), and yield response to (ii) one (124 data points) or three (25 data points) applications of fungicide, (iii) one application of tebuconazole (74 data points) or propiconazole (15 data points) and (iv) five growing seasons (1993, 1995, 1997, 1998 and 1999 with 17, 12, 21, 34 and 13 data points, respectively) with one application of fungicide.

A univariate rather than multivariate approach was chosen to demonstrate the impact of individual factors such as number of applications on yield response. Although a multivariate approach is useful, it needs to be used carefully because more assumptions do not always result in better inference (Jackson et al. 2011).

To investigate the seasonal variability in yield response, a relationship between total rainfall during late winter and early spring, when flag leaf emergence of the crop occurs, and yield response to one application of fungicide was examined. For this, historical rainfall data for 10 sites over 5 growing seasons (1993 [three locations], 1995 [four locations], 1997 [five locations], 1998 [five locations] and 1999 [three locations]) were obtained from weather stations of the Department of Agriculture and Food Western Australia.

The economic benefit of the yield response was calculated for two contrasting growing seasons, 1998 and 1999, for one and three applications of fungicide. For this analysis, today's wheat price was considered as US\$263 $\mathrm{t}^{-1}$, fungicide application cost as US\$10.52 ha ${ }^{-1}$, fungicide product cost $(63 \mathrm{~g}$ active ingredient $\mathrm{ha}^{-1}$ ) for one application as US\$5.05 ha ${ }^{-1}$ and for three applications as US $\$ 15.14 \mathrm{ha}^{-1}$. A conversion rate of one Australian dollar=1.0517 US dollar was used (Reserve Bank of Australia, www.rba.gov.au/statistics/ frequency/exchange-rates.html, accessed on 19 December 2012).

In meta-analysis, the use of confidence intervals (CI) is often suggested (Davis 2011; Cummings and Koepsell 2010; Gardner and Altman 1986). In this study, the standardised mean yield response was calculated with $95 \%$ CI (i.e. the true mean yield response is within the CI range (Davis 2011; Petrie and Sabin 2005)). Providing CI also allows determination of the statistical difference between two yield responses (Davis 2011).

For statistical comparison of yield response for a fungicide treatment to the control, the $P$ value was determined using a Z-test (Lipsey and Wilson 2001).

\section{Results}

Aggregated (or overall) response of wheat yield to fungicide

The untransformed wheat yield response to fungicide application ranged from -140 to $1,040 \mathrm{~kg} \mathrm{ha}^{-1}$. Approximately $11 \%$ of data points were $<0$ and $11 \%$ were $<50 \mathrm{~kg} \mathrm{ha}^{-1}$. The standardised yield response was $297 \mathrm{~kg} \mathrm{ha}^{-1}$. With the $95 \%$ confidence interval $(\mathrm{CI})$, this response ranged from 286 to $309 \mathrm{~kg} \mathrm{ha}^{-1}$. The $\mathrm{Z}$ statistic was $50.36(P<0.001)$. 
Effect of number of fungicide applications on wheat yield response

The standardised yield response was greater with three rather than one application of fungicides. The mean yield response for three applications of fungicide was $515 \mathrm{~kg} \mathrm{ha}^{-1}$ $\left(\mathrm{CI}=34 \mathrm{~kg} \mathrm{ha}^{-1}, P<0.001\right)$ compared to $212 \mathrm{~kg} \mathrm{ha}^{-1}$ $\left(\mathrm{CI}=21 \mathrm{~kg} \mathrm{ha}^{-1}, P<0.001\right)$ for a single application (Fig. 2). The difference in yield response between one and three applications of fungicide was statistically significant.

Effect of fungicide active ingredient on yield response

The standardised yield gain was greater for propiconazole (367 kg ha $\left.{ }^{-1}, P<0.001\right)$ than for tebuconazole $\left(165 \mathrm{~kg} \mathrm{ha}^{-1}\right.$, $P<0.001)$ for one application at the flag leaf to booting growth stage (Fig. 3). The CI (328 to $405 \mathrm{~kg} \mathrm{ha}^{-1}$ ) of propiconazole did not overlap with the CI (103 to $165 \mathrm{~kg} \mathrm{ha}^{-1}$ ) of tebuconazole, indicating that this difference was statistically significant.

Effect of growing season on yield response to fungicide

The mean wheat yield response to a single fungicide application differed among the five growing seasons (Fig. 4). The response was greatest in $1999\left(352 \mathrm{~kg} \mathrm{ha}^{-1}\right.$, CI 277$\left.427 \mathrm{~kg} \mathrm{ha}^{-1}, P<0.001\right)$ less in $1993\left(206 \mathrm{~kg} \mathrm{ha}^{-1}\right.$, CI 142$\left.270 \mathrm{~kg} \mathrm{ha}^{-1}, P<0.001\right)$ and least in $1998\left(79 \mathrm{~kg} \mathrm{ha}^{-1}, \mathrm{CI} 34-\right.$ $\left.124 \mathrm{~kg} \mathrm{ha}^{-1}, P<0.001\right)$. The CIs for 1993, 1995, 1997 and

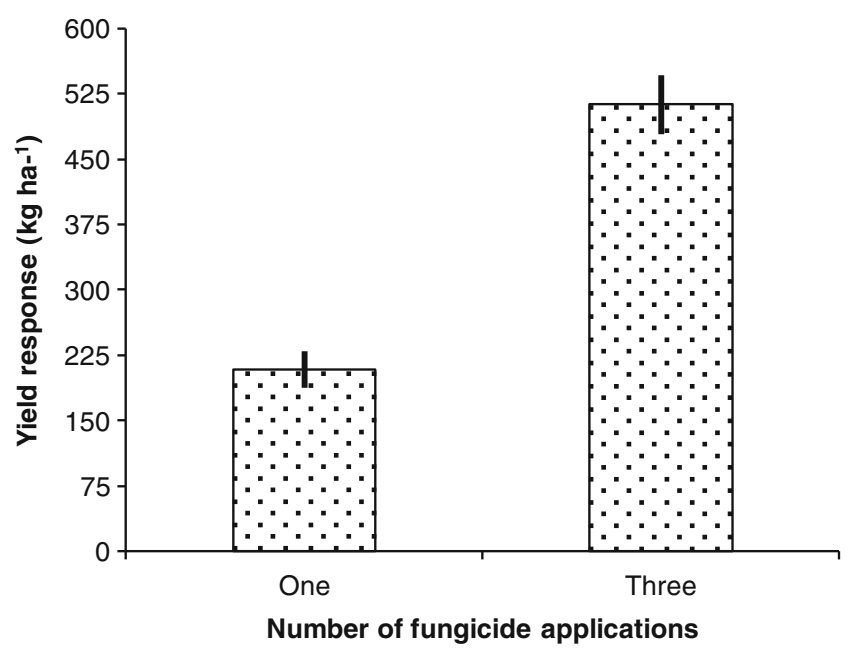

Fig. 2 Yield response to one $(N=124, S E=11, Z=19.4, P<0.001)$ or three $(N=25, S E=17.4, Z=29.6, P<0.001)$ fungicide application (compared to untreated control) for control of the yellow spot (Pyrenophora tritici-repentis) - septoria nodorum blotch (Stagonospora nodorum) disease complex on wheat in the northern grain-belt of the southwestern agricultural region of Western Australia. $\mathrm{N}$ is the number of data points, SE is the standard error of the yield responses, $\mathrm{Z}$ is the standard normal statistic. Vertical bars denote the $95 \%$ confidence intervals

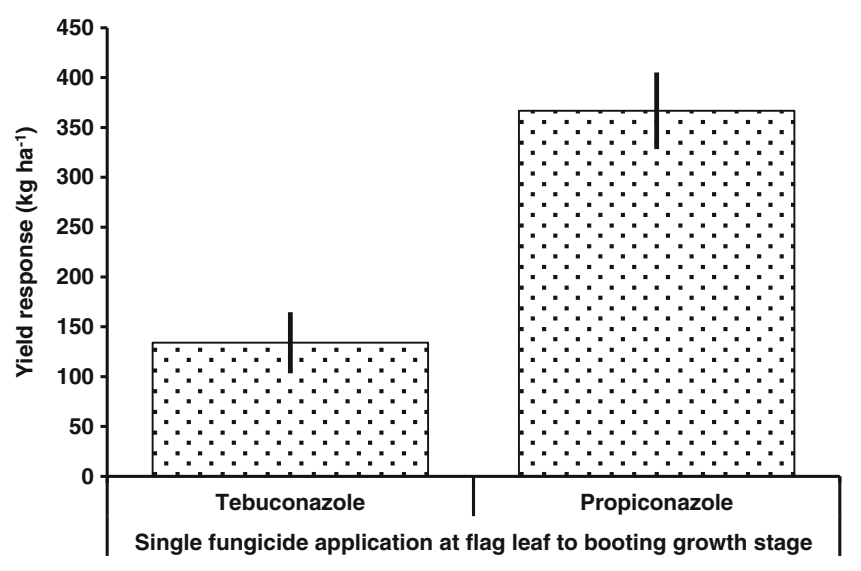

Fig. 3 Yield response to one application, at flag leaf to booting growth stage, of tebuconazole $(N=74, S E=15.6, Z=8.6, P<0.001)$ or propiconazole $(N=15, S E=19.6, Z=18.7, P<0.001)$ fungicide for control of the yellow spot (Pyrenophora tritici-repentis) - septoria nodorum blotch (Stagonospora nodorum) disease complex on wheat in the northern grain-belt of the south-western agricultural region of Western Australia. $\mathrm{N}$ is the number of data points, SE is the standard error of the yield responses, $\mathrm{Z}$ is the standard normal statistic. Vertical bars denote the $95 \%$ confidence intervals

1998 overlapped, suggesting the difference in yield response between them was not significant.

Relationship between rainfall and yield response

The yield response to a single fungicide application was greater in 1993, 1997 and 1999 when the crop received $\geq 100 \mathrm{~mm}$ rainfall during late winter and early spring (August-September) than in 1995 and 1998 when the crop received $\leq 70 \mathrm{~mm}$ rainfall during the same period (Fig. 5).

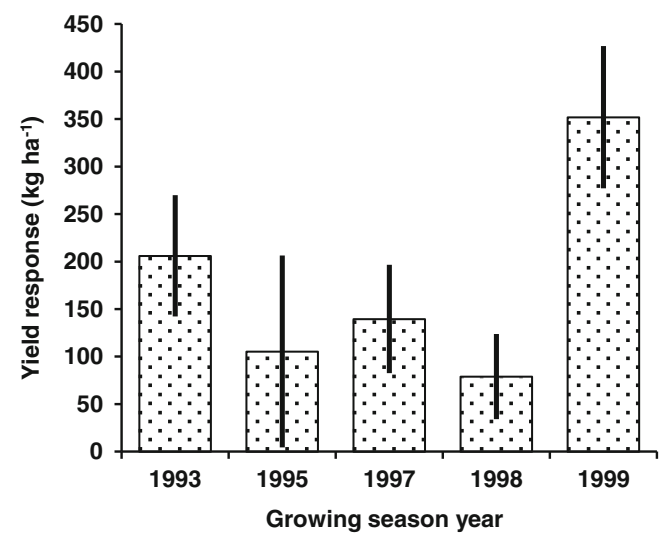

Fig. 4 Yield response to one application of fungicides to control the yellow spot (Pyrenophora tritici-repentis) - septoria nodorum blotch (Stagonospora nodorum) disease complex on wheat in the northern grain-belt of the south-western agricultural region of Western Australia in $1993(N=17, S E=32.6, Z=6.3, P<0.001), 1995(N=12, S E=51.6$, $Z=2.0, P<0.001), 1997(N=21, S E=29.1, Z=4.8, P<0.001), 1998$ $(N=34, S E=22.9, Z=3.5, P<0.001)$ and $1999(N=13, S E=38.2$, $Z=9.2, P<0.001) . \mathrm{N}$ is the number of data points, $\mathrm{SE}$ is the standard error of the yield responses, $\mathrm{Z}$ is the standard normal statistic. Vertical bars denote the $95 \%$ confidence intervals 


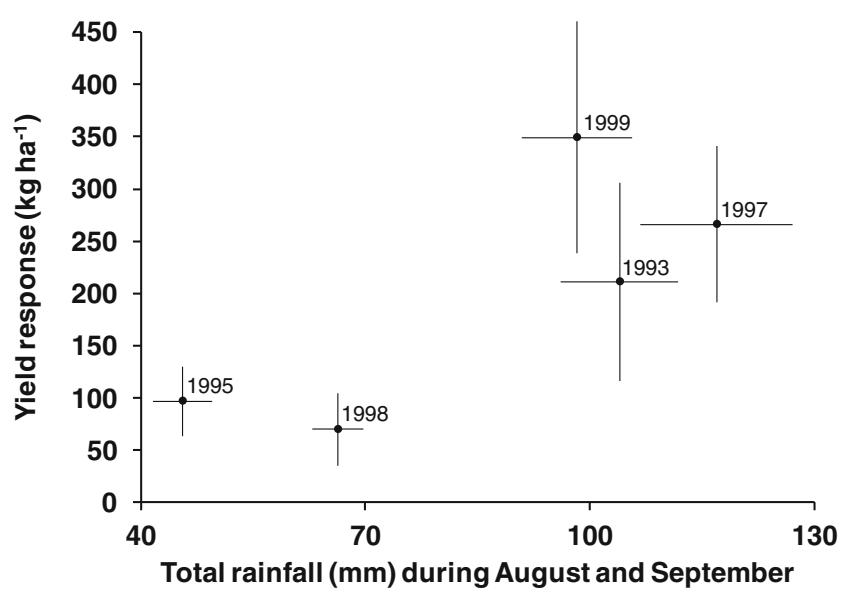

Fig. 5 Relationship between total rainfall during late winter and early spring (August-September) and yield response to one application of fungicides in different growing seasons (year) to control the yellow spot (Pyrenophora tritici-repentis) - septoria nodorum blotch (Stagonospora nodorum) disease complex on wheat in the northern grain-belt of the south-western agricultural region of Western Australia. Bars denote the $95 \%$ confidence intervals in yield response (vertical bars) and total rainfall (horizontal bars)

Yield response to fungicide application: economic return

The economic return to both one and three applications of fungicide was greater in 1999 than 1998. However, there was no significant difference between one and three applications of fungicide in either season (1998: one application US\$ $5 \mathrm{ha}^{-1}$ [CI of US\$ -7 to $17 \mathrm{ha}^{-1}$ ], three applications US $\$ 19 \mathrm{ha}^{-1}$ [CI of US\$ -14 to $52 \mathrm{ha}^{-1}$ ]; 1999: one application US\$77 ha ${ }^{-1}$ [CI of US\$ 57 to $97 \mathrm{ha}^{-1}$ ], three applications US\$ $101 \mathrm{ha}^{-1}$ [CI of US\$ 79 to $123 \mathrm{ha}^{-1}$ ]) (Fig. 6).

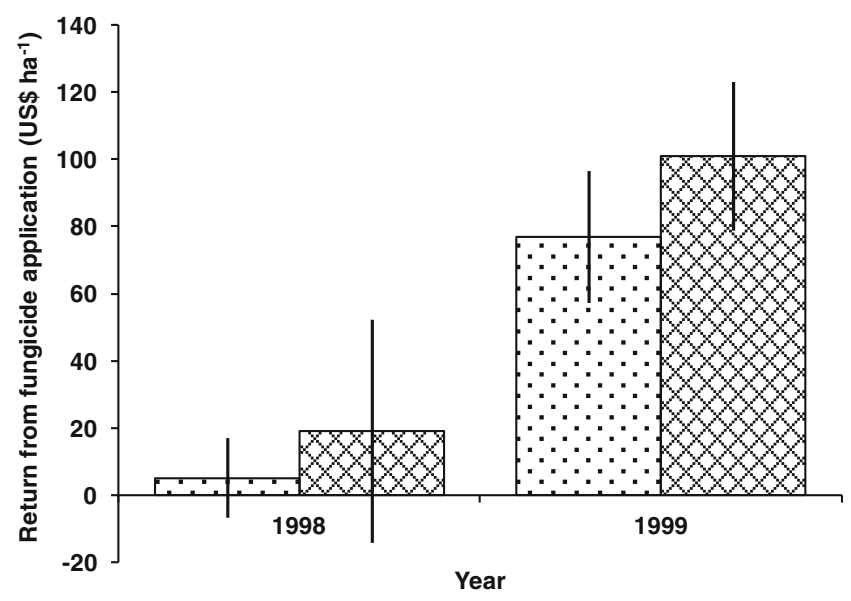

Fig. 6 Economic return, as of today's prices, from one (dotted bar) or three (crossed bar) applications of fungicides in 1998 and 1999 to control the yellow spot (Pyrenophora tritici-repentis)—septoria nodorum blotch (Stagonospora nodorum) disease complex on wheat in the northern grain-belt of the south-western agricultural region of Western Australia. Data used in Fig 2 were used in this analysis. Vertical bars denote the $95 \%$ confidence intervals

\section{Discussion}

Whilst these results demonstrate overall yield response of $297 \mathrm{~kg} \mathrm{ha}^{-1}$ to fungicide application to control the YS-SNB disease complex on wheat in Western Australia, this response is smaller than those reported elsewhere (Colson et al. 2003). This discrepancy may have occurred because the published literature accounted for a limited number of experiments from specific agro-environment(s) and growing seasonal conditions.

Three key questions often asked by the growers and other stakeholders in Western Australia in relation to controlling the YS-SNB disease complex on wheat are: what fungicide to use, how many applications of a fungicide are required, and how is the yield response influenced by the crop growing season. Choice of a product is an issue as a number of fungicides are available in the market to control the YSSNB. Among the available fungicides, propiconazole and tebuconazole are predominant. These results show a greater yield response to a single application at the wheat flag leaf stage for propiconazole than for tebuconazole as supported by other results (Beard et al. 2010; Loughman 2002; Platz 2011). The flag leaf emergence stage is widely recommended as the most appropriate time for a single fungicide application (Beard et al. 2005; Platz 2011). However, these results show yield response to a single application of fungicide at the flag leaf emergence stage was less than that to three applications of fungicide over a longer period of crop growth. Despite this greater disease control and yield response to three applications of fungicide, this work shows that the economic response did not differ between one and three fungicide applications, reflecting the increased input costs to achieve yield gains. Therefore, the results do not constitute a recommendation for use of multiple applications of fungicide to control the YS-SNB disease complex of wheat.

These results confirm the seasonal variability in yield response to fungicides to control YS-SNB disease complex on wheat in Western Australian environments (Loughman et al. 1994) and indicate that there is a relationship between yield response and rainfall during winter/spring (August and September). Rees and Platz (1980) suggest that rain periods lasting several days or a sequence of rain events promote development of the disease more effectively than brief isolated rain periods. Therefore, the seasons in which more rain fell in late winter and early spring (such as 1993, 1997 and 1999 compared to 1995 and 1998) were more favourable for disease development and consequently the use of fungicides resulted in greater yield responses.

This case study, using meta-analysis, has provided an overview of the effectiveness of fungicide control of yellow spot and septoria nodorum blotch disease complex in the northern grain-belt of the Western Australian south-western agricultural region under differing rainfall conditions. 
Additionally, it demonstrates how an overall or aggregated yield response can be further analysed to determine the influence of a range of contributing factors over a period of time. Future work is warranted to explore and quantify other causative variables in order to develop more comprehensive decision-making strategies for growers. Like any methodology, meta-analysis has common criticisms, but these can be accommodated if researchers use good judgement and in-depth knowledge of their research area in combining different experimental results and take due precaution in interpreting confidence intervals (Borenstein et al. 2009). It may be concluded that meta-analysis has great potential to contribute to understanding issues in plant pathology.

Acknowledgments We thank the Department of Agriculture and Food Western Australia (DAFWA) and Australian Grains Research and Development Corporation (GRDC) for financial assistance in this work through research project DAW00207 (National modelling, risk forecasting and epidemiology of crop diseases). Two anonymous reviewers made excellent editing of the manuscript; the senior author would especially like to record this with thanks.

Open Access This article is distributed under the terms of the Creative Commons Attribution License which permits any use, distribution, and reproduction in any medium, provided the original author(s) and the source are credited.

\section{References}

Adams, D. C., Gurevitch, J., \& Rosenberg, M. S. (1997). Resampling tests for meta-analysis of ecological data. Ecology, 78(5), 12771283.

Anderson, W., \& Garlinge. (2000). The wheat book principles and practice, Bulletin 4443. South Perth: Department of Agriculture and Food Western Australia.

Anonymous (2010a) Western Australian Statistical Indicators, 2010, Catalogue no 1367.5, Australian Bureau of Statistics.

Anonymous (2010b) Year Book Australia, 2009-10, Catalogue no 1301.0, Australian Bureau of Statistics.

Beard, C., Thomas, G., Jayasena, K., Salam, M., \& Loughman, R. (2005). Managing yellow spot and septoria of wheat. Department of Agricultural and Food Western Australia, Farmnote no. $59 / 2005$

Beard, C., Jayasena, K., Tanaks, K., \& Smith, A. (2010). Fungicide management of yellow spot in wheat, Agribusiness Crop Updates 2010. Department of Agriculture and Food Western Australia and Grains Research and Development Corporation.

Bhathal, J. S., Loughman, R., \& Speijers, J. (2003). Yield reduction in wheat in relation to leaf disease from yellow (tan) spot and septoria nodorum blotch. European Journal of Plant Pathology, 109, 435-443.

Borenstein, M., Hedges, L. V., Higgins, J. P., \& Rothstein, H. R. (2009). Introduction to meta-analysis (1st ed.). Ltd, UK: John Wiley and Sons.
Colson, E. S., Platz, G. J., \& Usher, T. R. (2003). Fungicidal control of Pyrenphora tritici-repentis in wheat. Australasia Plant Pathology, 32, 241-246.

Cooper, H. M. (1989). Integrating research: a guide for literature reviews (2nd ed.). Newbury Park, CA: Sage.

Cummings, P., \& Koepsell, T. D. (2010). P values vs estimates of association with confidence intervals. Archives of Pediatrics \& Adolescent Medicine, 164, 193-196.

Davis, H.T. (2011). What are confidence intervals? Hayward Medical Communications' evidence-based medicine (EBM) publication $3: 1-8$.

Gardner, M. J., \& Altman, D. G. (1986). Confidence intervals rather than $\mathrm{P}$ values: estimation rather than hypothesis testing. British Medical Journal, 292, 746-750.

Glass, G. (1976). Primary, secondary, and meta-analysis of research. Educational Research, 5, 3-8.

Jackson, D., Riley, R., \& White, I. R. (2011). Multivariate metaanalysis: potential and promise. Statistics in Medicine, 30, 2481-2498.

Lipsey, M. K., \& Wilson, D. B. (2001). Practical meta-analysis, applied social research methods series (Vol. 49). Thousand Oaks, California: Sage Publications.

Loughman, R. (2002). Fungicide strategies in integrated management of wheat and barley leaf diseases in southern WA. The Grains Research and Development Corporation and Department of Agriculture and Food Western Australia, A Final Report Summary. Eureka files. Available at: http:// www.grdc.com.au/GRDC/ResearchSummaries/CMAttachments/ daw589.pdf.

Loughman, R., Wilson, R. E., \& Thomas, G. J. (1994). The influence of disease complexes involving Leptosphaeria (Septoria) nodorum on detection of resistance to three leaf spot diseases in wheat. Euphytica, 72, 31-42.

Murray, G. M., \& Brennan, J. P. (2009). The current and potential costs from diseases of wheat in Australia. Barton: Grain Research and Development Corporation.

Ngugi, H. K., Lehman, B. L., \& Madden, L. V. (2011). Multiple treatment meta-analysis of products evaluated for control of fire blight in the Eastern United States. Phytopathology, 101, 512-522.

Petrie, A., \& Sabin, C. (2005). Medical statistics at a glance (2nd ed.). USA: Blackwell Publishing Ltd.

Platz. (2011). Yellow spot-managing high inoculum loads going into 2011 and a review of fungicide response. GRDC Research Updates 2011. Barton: Grains Research \& Development Corporation.

Rees, R. G., \& Platz, G. T. (1980). The epidemiology of yellow spot of wheat in Southern Queensland. Australian Journal of Agricultural Research, 31, 259-267.

Rosenberg, M. S., Garrett, K. A., Su, Z., \& Bowden, R. L. (2004) Meta-analysis in plant pathology: synthesizing research results. Phytopathology, 94, 1013-1017.

Shachar, M., \& Neumann, Y. (2003). Differences between traditional and distance education academic performances: A meta-analysis approach, The International Review of Research in Open and Distance Learning 4. Available at: http://www.irrodl.org/index.php/irrodl/article/view/153/234.

Shipton, W. A. (1971). The common septoria diseases of wheat. The Botanical Review, 37, 231-262.

Thompson, S. G., \& Pocock, S. J. (1991). Can meta-analyses be trusted? The Lancet, 338, 1127-1130.

Wiese, M. V. (1987). Compendium of wheat diseases (2nd ed.). St Paul, MN: American Phytopathological Society. 


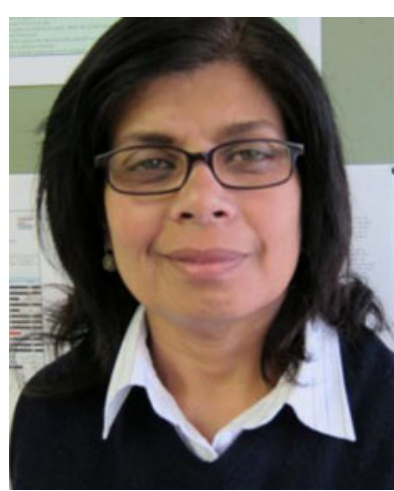

Dr. Kawsar Parveen Salam has been working in the discipline of Quantifying and Predicting Agricultural Systems in the Department of Agriculture and Food Western Australia (DAFWA) since 2004. She earned a PhD from Curtin University, Western Australia in 2010. In DAFWA, Dr. Salam is especially responsible for co-ordinating, information packaging and delivering forecasts of risk of crop diseases in broad-acre crops in southern Australia. Dr. Salam is a qualified meta-analyst and is interested in analysis of data related to crop diseases.

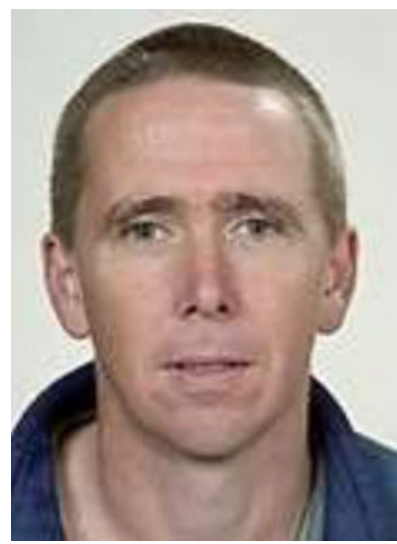

Mr Geoffrey (Geoff) John Thomas is a plant pathologist in the discipline of Integrated Pest and Disease Management at the Department of Agriculture and Food, Western Australia (DAFWA). He graduated from the University of Western Australia. His early research was concerned with diseases of lupins, especially anthracnose. In recent years, Mr. Thomas's research has concentrated on integrated management of cereal crop diseases in the medium and high rainfall regions of the Western Australian grain-belt

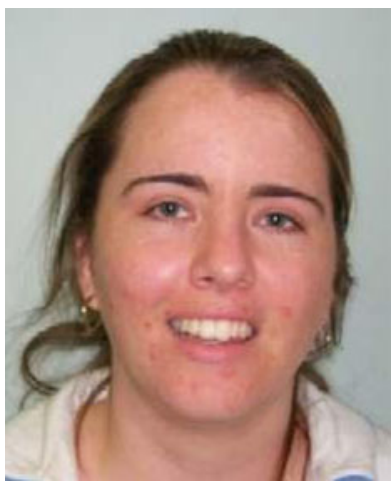

Ms Ciara Beard is a plant pathologist with the Department of Agriculture and Food Western Australia (DAFWA) and is based at Geraldton in the north of the Western Australian grain-belt. Ms Beard works in the discipline of Integrated Pest and Disease Management and her research interests have focussed on diseases of cereal crops under onfarm conditions in the northern region of Western Australian grain-belt.

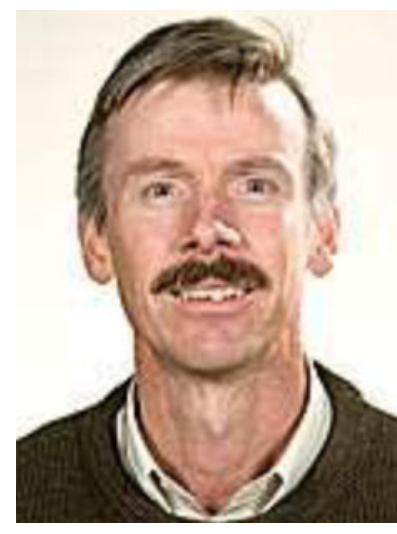

Dr Robert Loughman received his $\mathrm{PhD}$ from the University of Sydney. Currently, he is the Leader of Grain Quality Genetics of the Australian Export Grains Innovation Centre (AEGIC) Dr. Loughman is regarded as one of the leading cereal pathologists in Australia. Before taking on his current role, he led cereal pathology and disease resistance breeding at the Department of Agriculture and Food, Western Australia (DAFWA) and acted as Director of Grains Quality and Product Innovation at DAFWA's Grains Industry Directorate.

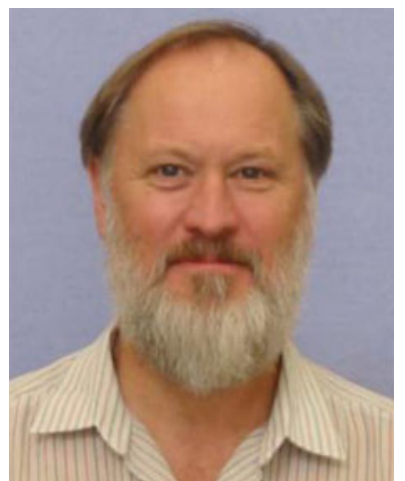

Mr William James (Bill) Macleod graduated from the University of Western Australia and is a Senior Plant Pathologist and Section Manager of Integrated Pest and Disease Management at the Department of Agriculture and Food Western Australia (DAFWA). Mr MacLeod leads research and development to minimise the impact of foliar and root diseases on cereals, canola and legume crops grown in the grain belt of Western Australia. He is regarded as one of the leading experts on pulse diseases in Australia. Currently, he is the Vice President of the Australasian Plant Pathology Society.

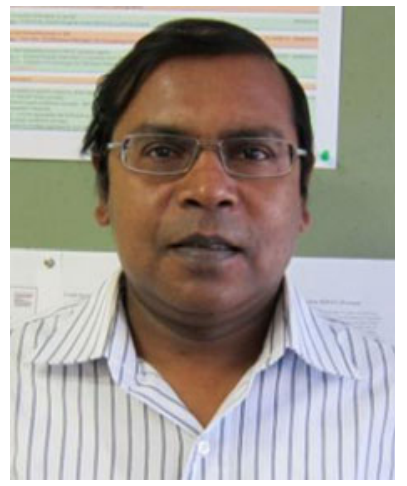

Dr. Moin Us Salam is a Principal research Officer in the Department of Agriculture and Food, Western Australia (DAFWA). He is an agricultural systems modeller and Discipline Leader for "Quantifying and Predicting Agricultural Systems" in DAFWA. Dr. Salam received his $\mathrm{PhD}$ from the University of Reading, UK and, after graduating, further studied agricultural systems and modelling as Adjunct Associate Professor at the University of Florida, Gainesville, USA. During the last 25 years, he has developed a number of nationally and internationally recognised crop growth and crop disease epidemiological models. Together with Professor Kazuhiko Kobayashi of Tokyo University, Dr Salam developed MSD (mean squared deviation) based analysis to compare output of a mechanistic model with observation, which has now become an internationally used tool. Currently, he is leading the research programme, "National modelling, risk forecasting and epidemiology of crop diseases". 